ISSN 1112-9867

Available online at

http://www.jfas.info

\title{
CORRELATION STUDY AMONG WATER QUALITY PARAMETERS OF GROUNDWATER OF VALSAD DISTRICT OF SOUTH GUJARAT (INDIA)
}

\author{
P. Shroff ${ }^{1}$, R. T. Vashi ${ }^{1, *}$, V. A. Champaneri ${ }^{2}$ and K. K. Patel ${ }^{1}$ \\ ${ }^{1}$ Department of Chemistry, Navyug Science College, Surat-395009, (Gujarat), India. \\ ${ }^{2}$ Department of Chemistry, B.K.M. Science College, Thital Road, Valsad-396001.
}

Received: 27 March 2015 / Accepted: 05 August 2015 / Published online: 1 September 2015

\begin{abstract}
Groundwater samples were collected from five talukas of Valsad district for one year (from August 2008 to July 2009) and were analyzed for their physicochemical characteristics. The present investigation is focused on determination of parameters like $\mathrm{pH}$, Colour, Electrical Conductivity (EC), Total Hardness (TH), Calcium (Ca), Magnesium (Mg), Total Alkalinity (TA), Total Dissolved Solids (TDS), Silica, Chloride, Sulphate, Fluoride, Sodium, Chemical Oxygen Demand (COD) and metals like Copper $(\mathrm{Cu})$ and Manganese $(\mathrm{Mn})$. Correlation coefficients were determined to identify the highly correlated parameters and interrelated water quality parameters. Correlation matrix of Valsad district suggests that EC of groundwater is found to be significantly correlated with eight out of seventeen water quality parameters studied. It may be suggested that the quality of Valsad district can be checked very effectively by controlling EC of water.
\end{abstract}

Keywords: Ground Water; Correlation; Valsad District; Gujarat.

Author Correspondence, e-mail: vashirajendra@yahoo.co.in

doi: http://dx.doi.org/10.4314/jfas.v7i3.3 


\section{INTRODUCTION}

The effect of water on almost everything in our environment is far more consequential than might be imagined. The fresh or potable water, although renewable, is very limited and vulnerable resource. There is growing shortage of usable water resources and it is going to be one of the major issues of the twenty first century [1].

Groundwater is the major source of water supply for domestic purposes in urban as well as rural parts of India. Among the various reasons, the most important are non-availability of potable surface water and a general belief that groundwater is purer and safer than surface water due to earth mantle covering. But contrary to that, presence of more than 200 chemicals constituents in groundwater has been documented which includes about 175 organic and more than 50 inorganic and radio nucleotides. The sources of these chemicals are both natural and anthropogenic. Once the ground water is contaminated, it may remain in an unusual or even in hazardous condition for decades or even centuries [2]. Thus, every effort should be made to achieve a dirking water quality as safe as possible. A critical step in assuring the quality of drinking water resources is to identify the cause of current or potential contamination problems. Testing of water quality on a regular basis is, therefore, an important part of maintaining a safe and reliable source. The test results allow one to properly address the specific problems of water sources properly [1]. Water quality studies are regarded as one of the thrust areas in water resources sector, as envisaged in the National Water Policies 1987 and 2002 that both surface water and ground water should be regularly monitored, and a phased program should be undertaken for improvements in water quality [3]. A number of techniques and methods have been developed to interpret the chemical data. Zaporozec summarized the various modes of data representation and discussed their possible uses [4]. The task of monitoring the quality of water is facilitated if one can find some correlation among these numerous parameters. When such correlation do exists, then by measuring a few important parameters one can easily calculate the remaining parameters and the quality of water can be easily and quickly assessed [5].

The present study was undertaken to find out the correlation between water quality parameters of groundwater of Valsad district. Valsad district is located in South Gujarat, at the bank of Arabian Sea. The district is lying between $20^{\circ} 8^{\prime}$ to $21^{0} 9^{\prime} \mathrm{N}$ latitudes, and $62^{\circ} 39^{\prime}$ to $73^{\circ} 30^{\prime}$ E longitudes. The area is 2947 sq.km. The district is reach in forest area i.e. 1249 sq. km. land is occupied by thick forest. 


\section{MATERIALS AND METHODS}

Valsad district has five talukas namely Valsad, Pardi, Umargam, Kaprada and Dharampur. Three sampling stations from each taluka were selected on basis of the location demand. Total fifteen sampling stations are selected for correlation study of groundwater of Valsad district. The sampling stations designated S1 to S15. The location of sampling stations is shown in Fig. 1.

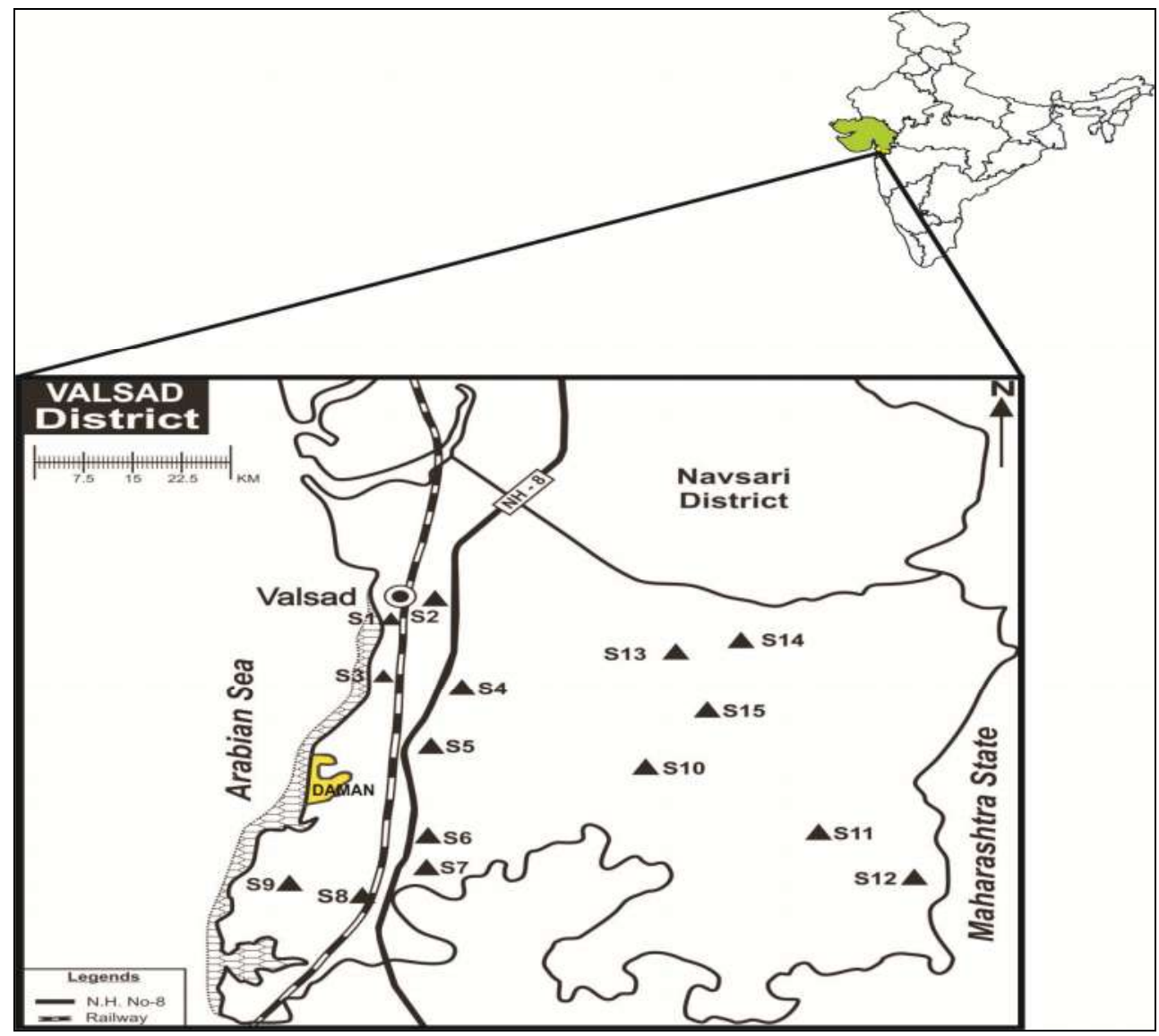

Fig.1. Location of sampling stations

The groundwater samples were collected in two litre polythene bottles which were thoroughly washed twice with the water to be analyzed. The physico-chemical parameters like $\mathrm{pH}, \mathrm{EC}$, color, Total Hardness(TH), Calcium, Magnesium, Total Alkalinity(TA), Total Dissolved Solids (TDS), Silica, Chloride, Sulphate, Fluoride, Sodium, COD and metals like Copper (Cu) and Manganese (Mn) were estimated as per APHA [6]. The task of monitoring the quality of water is facilitated if one can find some correlation among these numerous parameters. When such correlation do exists, then by measuring a few important parameters one can easily calculate the 
remaining parameters and the quality of water can be easily and quickly assessed [5]. Correlation indicates association between two variables. The correlation coefficient was obtained from such two variables is known as correlation coefficient. It is also known as degree of association between given two variables.

Karl Pearson's measure, known as Pearson's correlation coefficient between two variable series $\mathrm{X}$ and $\mathrm{Y}$, usually denoted by $\mathrm{r}$ and is defined [6] as the ratio of the covariance between $\mathrm{X}$ and $\mathrm{Y}$, written as $\operatorname{cov}(\mathrm{X}, \mathrm{Y})$, to the product of the standard deviations of $\mathrm{X}$ and $\mathrm{Y}$, symbolically,

$$
r=\frac{\operatorname{Cov}(\mathrm{X}, \mathrm{Y})}{\sigma x \sigma y}
$$

If $\left(\mathrm{x}_{1}, \mathrm{y}_{1}\right),\left(\mathrm{x}_{2}, \mathrm{y}_{2}\right), \ldots\left(\mathrm{x}_{n}, \mathrm{y}_{n}\right)$ are $\mathrm{n}$ pairs of the variables $\mathrm{X}$ and $\mathrm{Y}$ in a bivariate distribution, then,

$$
\begin{aligned}
\operatorname{Cov}(\mathrm{X}, \mathrm{Y}) & =\sum \frac{(\mathrm{dx})(\mathrm{dy})}{\mathrm{n}} \\
\sigma \mathrm{x} & =\left[\sum \frac{(\mathrm{dx})^{2}}{\mathrm{n}}\right]^{\frac{1}{2}} \\
\sigma \mathrm{y} & =\left[\sum \frac{(\mathrm{dy})^{2}}{\mathrm{n}}\right]^{\frac{1}{2}}
\end{aligned}
$$

Substituting values from equation (3) in (2) we get,

$$
\begin{aligned}
& r=\frac{\operatorname{Cov}(\mathrm{X}, \mathrm{Y})}{\sigma \mathrm{x} \sigma \mathrm{y}} \\
& \mathrm{r}=\left[\frac{\sum \frac{(\mathrm{dx})(\mathrm{dy})}{\mathrm{n}}}{\left(\sum \frac{(\mathrm{dx})^{2}}{\mathrm{n}}\right)^{\frac{1}{2}}\left(\sum \frac{(\mathrm{dy})^{2}}{\mathrm{n}}\right)^{\frac{1}{2}}} .\right. \\
& \mathrm{r}=\frac{\sum(\mathrm{dx} \cdot \mathrm{dy})}{\left[\Sigma(\mathrm{dx})^{2} \sum(\mathrm{dy})^{2}\right]^{\frac{1}{2}}}
\end{aligned}
$$

Where, 
$r$ is the correlation coefficient, $\mathrm{x}$ and $\mathrm{y}$ are the two variables, $\mathrm{dx}$ is the deviation from $\mathrm{x}$-mean of the $\mathrm{x}$ variable, $\mathrm{dy}$ is the deviation from $\mathrm{y}$-mean of the $\mathrm{y}$ variable, $\sum(\mathrm{dx} . \mathrm{dy})$ is the sum of the products of the deviations, $\sum(\mathrm{dx})^{2}$ is the sum of the squares of the deviation of the $\mathrm{x}$ variable, $\sum(\mathrm{dy})^{2}$ is the sum of the squares of the deviation of the $y$ variable

\section{RESULTS AND DISCUSSION}

The $\mathrm{pH}$ value of groundwater is an important index of acidity and alkalinity and the resulting value of the acidic-basic interaction of a number of its mineral and organic components. Color in water may result from the presence of natural metallic ions (iron and manganese), humus and peat materials, plankton, weeds, and industrial wastes. Some researchers identified that the water quality can be predicted with sufficient accuracy just by measurement of EC alone [5]. EC is highly correlated with eight parameters of present study. Hardness of water may be temporary or permanent. Temporary hardness is mainly due to the presence of calcium, magnesium and bicarbonates. Permanent hardness is due to the presence of sulphates and chlorides of calcium and magnesium [8]. The presence of carbonates, bicarbonates and hydroxides are the main cause of alkalinity in natural waters [9]. There is a large variation in Total dissolved solids (TDS) values.

Most of the water samples contained appreciable amount of chloride. Chloride ion is one of the major inorganic anions in water. Large amounts of $\mathrm{Cl}$ when $\mathrm{Ca}$ and $\mathrm{Mg}$ are also present, lead to increase in water's corrosiveness [10]. The high values of COD will most seriously pollute the surroundings water bodies. It may cause harm to soil hydraulic properties in the long run [11]. Metals with specific gravity greater than 5 or often more are termed as heavy metals. Copper is essential component of several enzymes [2]. Sodium occurs as a major cation in water samples [9]. The extent of replacement of other cation by sodium is denoted by Sodium Absorption Ratio (SAR) defined by following equation [12].

$$
\mathrm{SAR}=\frac{\mathrm{Na}^{+}}{\sqrt{\left(\frac{\mathrm{Ca}^{+2}+\mathrm{Mg}^{+2}}{2}\right)}}
$$


Fluoride contamination in ground water has now become a major geo-environment issue in many parts of the world due to its toxic effects even if consumed in trace quantities. India is among 23 nations around the globe, where health problems occur due to the consumption of fluoride contaminated water [13].

The result of groundwater analysis for study period Aug 2008 - July 2009 is shown in Table 1 with range, mean value and standard deviation.

Table 1. Results of groundwater analysis of Valsad district

\begin{tabular}{cllll}
\hline $\begin{array}{c}\text { Sr. } \\
\text { No. }\end{array}$ & Parameter & Range & Mean & $\begin{array}{l}\text { Standard } \\
\text { Deviation }\end{array}$ \\
\hline 1 & $\mathrm{pH}$ & $6.4-8.3$ & 7.4 & \pm 0.327 \\
2 & Color & $1-20$ & 4 & \pm 2.611 \\
3 & EC & $0.18-3.4$ & 0.847 & \pm 0.715 \\
4 & Total Hardness as $\mathrm{CaCO}_{3}$ & $70-1040$ & 360 & \pm 218.582 \\
5 & $\mathrm{Ca}$ & $17-267$ & 85 & \pm 52.921 \\
6 & $\mathrm{Mg}$ & $4-132$ & 36 & \pm 23.810 \\
7 & Total Alkalinity as $\mathrm{CaCO}_{3}$ & $65-570$ & 262 & \pm 118.082 \\
8 & TDS & $158-3080$ & 764 & \pm 649.098 \\
9 & Silica & $10-47$ & 25 & \pm 4.892 \\
10 & Chloride as $\mathrm{Cl}$ & $6-1180$ & 177 & \pm 274.767 \\
11 & Sulfate & $5-103$ & 27 & \pm 22.380 \\
12 & COD & ND-28 & 6.2 & \pm 3.655 \\
13 & Cu & BDL-0.03 & 0.00093 & \pm 0.002 \\
14 & Mn & BDL-0.61 & 0.05 & \pm 0.097 \\
15 & Sodium Absorption Ratio & $0.41-13.38$ & 2.52 & \pm 2.802 \\
16 & Fluoride & $0.14-0.48$ & 0.32 & \pm 0.108 \\
17 & Sodium & $10-837$ & 125.5 & \pm 177.597 \\
\hline Results are expressed in mg/l except for $\mathrm{pH}, \mathrm{Colour}$ in Hazen and $\mathrm{EC}$ in $\mathrm{mmho} / \mathrm{cm}$ )
\end{tabular}

(ND : Not Detected; BDL : Below Detectable Limit)

Correlation is the mutual relationship between two variables. Direct correlation exists when increase or decrease in the value of one parameter is associated with a corresponding increase or decrease in the value of the other. The correlation is said to be positive when increase in one parameter causes the increase in other parameter and it is negative when increase in one parameter causes decrease in the other parameter. The correlation coefficient $(r)$ has a value between +1 and -1 . The correlation between the parameters is characterized as strong, when it is in the range of \pm 0.8 to \pm 1.0 , moderate in the range of \pm 0.5 to \pm 0.8 , weak when in the range of 0.0 
to \pm 0.5 [14]. The correlation coefficient ( $\mathrm{r}$ ) among various water quality parameters was calculated and the values of the correlation coefficients were given in the Table 2 . 
Table 2. Correlation coefficient matrix of physico-chemical parameters for Valsad District (Aug 2008 to July 2009)

\begin{tabular}{|c|c|c|c|c|c|c|c|c|c|c|c|c|c|c|c|c|c|}
\hline Parameter & $\mathbf{p H}$ & Color & EC & TH & $\mathrm{Ca}$ & Mg & $\mathbf{T A}$ & TDS & Silica & Chloride & Sulphate & COD & $\mathbf{C u}$ & Mn & SAR & Fluoride & Sodium \\
\hline pH & 1.00 & & & & & & & & & & & & & & & & \\
\hline Color & 0.45 & 1.00 & & & & & & & & & & & & & & & \\
\hline EC & -0.14 & -0.20 & 1.00 & & & & & & & & & & & & & & \\
\hline TH & -0.30 & -0.04 & 0.88 & 1.00 & & & & & & & & & & & & & \\
\hline $\mathrm{Ca}$ & -0.39 & -0.30 & 0.74 & 0.96 & 1.00 & & & & & & & & & & & & \\
\hline Mg & -0.15 & -0.17 & 0.97 & 0.93 & 0.80 & 1.00 & & & & & & & & & & & \\
\hline TA & 0.06 & 0.05 & 0.84 & 0.76 & 0.64 & 0.84 & 1.00 & & & & & & & & & & \\
\hline TDS & -0.14 & -0.20 & 0.99 & 0.88 & 0.74 & 0.97 & 0.84 & 1.00 & & & & & & & & & \\
\hline Silica & -0.47 & -0.12 & 0.02 & 0.26 & 0.34 & 0.13 & -0.15 & 0.02 & 1.00 & & & & & & & & \\
\hline Chloride & -0.18 & -0.22 & 0.98 & 0.84 & 0.69 & 0.93 & 0.76 & 0.98 & -0.02 & 1.00 & & & & & & & \\
\hline COD & 0.08 & 0.21 & -0.13 & -0.10 & -0.15 & -0.01 & -0.05 & -0.13 & 0.07 & -0.21 & -0.12 & 1.00 & & & & & \\
\hline $\mathrm{Cu}$ & 0.16 & 0.46 & 0.35 & 0.18 & 0.002 & 0.41 & 0.43 & 0.35 & -0.14 & 0.34 & 0.44 & 0.31 & 1.00 & & & & \\
\hline Mn & 0.11 & 0.35 & -0.21 & -0.18 & -0.14 & -0.22 & 0.05 & -0.21 & -0.49 & -0.21 & -0.31 & 0.23 & 0.17 & 1.00 & & & \\
\hline SAR & 0.11 & -0.05 & 0.90 & 0.61 & 0.40 & 0.82 & 0.78 & 0.90 & -0.24 & 0.91 & 0.83 & -0.15 & 0.49 & -0.15 & 1.00 & & \\
\hline Fluoride & 0.48 & 0.35 & 0.26 & 0.11 & 0.00 & 0.25 & 0.53 & 0.26 & -0.34 & 0.19 & 0.18 & 0.21 & 0.44 & 0.18 & 0.47 & 1.00 & \\
\hline Sodium & 0.004 & -0.10 & 0.95 & 0.71 & 0.52 & 0.88 & 0.80 & 0.95 & -0.17 & 0.96 & 0.89 & -0.17 & 0.45 & -0.16 & 0.99 & 0.36 & 1.00 \\
\hline
\end{tabular}


The strong positive correlation between $\mathrm{EC}$ and $\mathrm{TH}(0.88), \mathrm{Ca}(0.97), \mathrm{TA}(0.84)$, TDS(0.99), Chloride(0.98), Sulphate(0.94), Sodium(0.95), SAR(0.90) were found. The moderate correlation between $\mathrm{EC}$ and $\mathrm{Ca}(0.74), \mathrm{TH}$ and $\operatorname{SAR}(0.61)$, Sodium(0.71). $\mathrm{Ca}$ and $\mathrm{TA}(0.64), \operatorname{TDS}(0.74)$, $\mathrm{Cl}(0.69)$, Sulphate(0.70) were found. Fluoride, $\mathrm{Mn}, \mathrm{Cu}, \mathrm{COD}$ and Silica were showing weak correlation with the other parameters.

\section{CONCLUSION}

The statistical analysis of the experimentally estimated water quality parameters on water samples yielded the range of variation, mean, standard deviation and coefficient of variation. Since the correlation coefficient gives the interrelationship between parameters, correlation coefficients were calculated. Results of correlation analysis show that EC shares strong and positive correlation with Total hardness, Magnesium, Total alkalinity, TDS, Chloride, Sulphate, Sodium and SAR, On basis of above discussion it may be concluded that EC of water is an important drinking water parameter as it significantly correlated with eight out of seventeen parameters in the study area.

\section{ACKNOWLEDGEMENT}

The authors are thankful to Department of chemistry, Navyug Science college, Surat for providing the laboratory facility required to carry out the present work.

\section{REFERENCES}

[1] Buragohain M., Bhuyan B, Sarma K P, J. Envi. Sci. and Engg, 2010, 52(3), pp. 241-244.

[2] Mishra P.C., Behera P.C., Patel R.K, J. Envi. Sci. and Engg, 2005, 47(2), pp. 141-154.

[3] Singh O., Kumar V., Rai S.P, J. Envi. Sci. and Engg. 2005, 47(1), pp. 25-32.

[4] Zaporozec A., groundwater, 1972, 10, pp. 32-43.

[5] Bhasin S.K, Singh A., Kaushal J, J. Envi. Res. and Develop, 2008, 2(3).

[6] American Public Health Association, Standard Methods for the Examination of Water and Waste Water, $20^{\text {th }}$ edition, Washington D.C, 1998.

[7] Pachchigar J.J, Studies of groundwater and surface water quality of Choryasi taluka (Surat), Thesis, Veer Narmad South Gujarat University, Surat, 2010. 
[8] Begum N., Purushothama R., Narayana J., Ravindrakumar K.P, J. Envi. Sci. and Engg, 2006, 48(4), pp. 281-284.

[9] Sharma M.K, Jain C.K, J. Envi. Sci. and Engg, 2006, 48(4), pp. 271-280.

[10] Anamika, Asian J. of Chemistry, 2008, 20(6), pp. 4659-4663.

[11] Pandey R., Singh V.K., Singh J, Information brochure on Audyogik apshisht jal ka prabandhan avum krishi me punah upyog, 2003.

[12] Chopra S.L., Kanwar J.S, Analytical Agriculture Chemistry, Kalyani Publication, 1999, pp. 292.

[13] Vikas C, J. Envi. Sci. and Engg., 2009, 51(3), pp. 169-174.

[14] Nair A., Abdullan G., Mohmmad I., Fadiel M., Poll Res, 2005, 24(1), pp. 1-6.

How to cite this article:

Shroff P, Vashi R T, Champaneri V A and Patel K K. Correlation study among water quality parameters of groundwater of valsad district of south gujarat (India). J. Fundam. Appl. Sci., 2015, 7(3), 340-349. 